\title{
OPEM
}

www.opem.org

Oriental Pharmacy and Experimental Medicine 2007 7(4), 341-347

DOI 10.3742/OPEM.2007.7.4.341

\section{Ethanol extract of Callophyllis japonica enhances nitric oxide and tumor necrosis factor-alpha production in mouse macrophage cell line, RAW 264.7 cells}

\author{
Meejung Ahn ${ }^{1,2,3}$, Dal-Soo Park ${ }^{1}$, Won-Hyung Yang ${ }^{1}$, Gyung-Min Go ${ }^{4}$, Hyung-Min Kim ${ }^{5}$, Jin- \\ Won Hyun ${ }^{2,6}$, Jae-Woo Park ${ }^{7}$ and Taekyun Shin ${ }^{1,2,3, *}$ \\ ${ }^{1}$ Department of Veterinary Medicine, Cheju National University, Jeju 690-756, Republic of Korea; ${ }^{2}$ Applied \\ Radiological Science Research Institute, Cheju National University, Jeju, Republic of Korea; ${ }^{3}$ Research Institute \\ for Subtropical Agriculture and Biotechnology, , Cheju National University, Jeju, Republic of Korea; ${ }^{4}$ Provincial \\ Fisheries Resources Research Institute, Jeju 699-810, Republic of Korea; ${ }^{5}$ Department of Pharmacology, College \\ of Oriental Medicine, Kyung Hee University, Seoul 130-701, Republic of Korea; ${ }^{6}$ Department of Biochemistry, \\ College of Medicine, Cheju National University, Jeju, Republic of Korea; ${ }^{7}$ Department of Nuclear and Energy \\ Engineering, College of Engineering, Cheju National University, Jeju 690-756, Republic of Korea
}

\begin{abstract}
SUMMARY
Red seaweed (Callophyllis japonica) has long formed part of the diet of Asians, but the pharmacological properties of this plant have not been evaluated. In this study, we examined the effect of an ethanol extract of $C$. japonica on the generation of nitric oxide (NO) in RAW 264.7 cells. The $C$. japonica extract increased the generation of $N O$ and tumor necrosis factor- $\alpha$ (TNF- $\alpha$ ), which were detected by the Griess method and an enzyme-linked immunosorbent assay, respectively. The increased production of $\mathrm{NO}$ by $\mathrm{C}$. japonica extract was inhibited by $\mathrm{N}^{\mathrm{G}}$-monomethyl-L-arginine $(100 \mu \mathrm{M})$, a specific inhibitor of NO production in the L-arginine-dependent pathway, and by the nuclear factor- $\kappa \mathrm{B}(\mathrm{NF}-\kappa \mathrm{B})$ inhibitor, pyrrolidine dithiocarbamate $(10-100 \mu \mathrm{M})$ in a dose-dependent manner. These findings demonstrate that $C$. japonica extract stimulates the production of NO and TNF- $\alpha$ in RAW 264.7 cells through the activation of NF- $\kappa B$ and that this extract might also inhibit the growth of the human leukemic cells.
\end{abstract}

Key words: Callophyllis japonica; Red seaweed; Nitric oxide; RAW 264.7 cells; Tumor necrosis factor- $\alpha$

\section{INTRODUCTION}

Nitric oxide (NO) is a highly reactive molecule that is produced from arginine by NO synthase (NOS) (Nathan et al., 1991). NO has received increasing attention as a potent macrophage-derived effecter molecule that is effective against a variety of

*Correspondence: Tae-Kyun Shin, Department of Veterinary Medicine, Cheju National University, Jeju 690-756, Republic of Korea. Tel: +82-64-754-3363; Fax: +82-64-756-3354; E-mail: shint@cheju.ac.kr bacteria, parasites, and tumors (Gantt et al., 2001). For example, mice treated with a NOS inhibitor and inducible NOS knockout mice were reported to be more susceptible to bacterial infection than untreated and wild-type animals, respectively (Zhou et al., 2002). Reactive oxygen and nitrogen intermediates produced in innate immune cells would be effective in the host defense mechanism against microbial pathogens. Although the precise mechanism by which NO antagonizes bacterial infection is not known, the mechanism may 
involve disruption of bacterial DNA, proteins, and signaling or the induction of apoptosis in macrophages that harbor mycobacteria (Chung et al., 2002). In addition to the involvement of $\mathrm{NO}$ in the process of inflammation, vascular hemodynamics are greatly affected by NO.

Callophyllis japonica (C. japonica), a red seaweed, has been traditionally eaten in the oriental food for diet, the biological activity of $C$. japonica have been limited yet. Recently, we reported that $C$. japonica exhibits antioxidant properties through the increased activities of the cellular antioxidant enzymes, superoxide dismutase and catalase in Chinese hamster lung fibroblast line V79-4 (Kang et al., 2005) and it has a hepatoprotective effect on chemical-induced liver injury (Park et al., 2005).

The aim of this study is to examine the effects of an ethanol extract of $C$. japonica on NO production in vitro.

\section{MATERIALS AND METHODS}

\section{Preparation of seaweed}

Fresh $C$. japonica plants were obtained from a local marine market on Jeju Island, South Korea. The plants were confirmed to be C. japonica by a taxonomist (Prof. YP Lee, Cheju National University) and the specimens were kept for reference. The plants were washed several times with distilled water, soaked in $70 \%$ ethanol, and dried for $48 \mathrm{~h}$ at room temperature. The ethanol-soluble fraction was filtered and the supernatant was concentrated by rotary evaporation. The resulting concentrate was freeze-dried to yield a brown powder $(5 \%$ yield, $\mathrm{w} / \mathrm{w}$ ), which was dissolved in phosphate-buffered saline (PBS) for in vitro experiments.

\section{Cell cultures}

A mouse macrophage-like cell line, RAW 264.7, was maintained at $37^{\circ} \mathrm{C}$ in an incubator with a humidified atmosphere of $5 \% \mathrm{CO}_{2}$. Cells were cultured in RPMI-1640 medium containing 10\% heat-inactivated fetal calf serum, streptomycin (100 $\mu \mathrm{g} / \mathrm{ml})$, and penicillin $(100 \mathrm{U} / \mathrm{ml})$.

\section{Chemicals}

Pyrrolidine dithiocarbamate (PDTC) and $\mathrm{N}^{\mathrm{G}}$ monomethyl-L-arginine (NMMA) were purchased from Calbiochem (San Diego, CA, USA). A mouse tumor necrosis factor (TNF)- $\alpha$ enzyme-linked immunosorbent assay kit was purchased from $\mathrm{R}$ \& D Systems (Minneapolis, MN, USA). The remaining chemicals and reagents used were of analytical grade.

\section{Measurement of nitrite concentrations and TNF- $\alpha$ release}

RAW 264.7 cells were seeded at $1 \times 10^{5}$ cells $/ \mathrm{ml}$. After $16 \mathrm{~h}$, the cells were treated with various concentrations of the C. japonica ethanol extract. The cells were then incubated for an additional $48 \mathrm{~h}$ at $37^{\circ} \mathrm{C}$. NO synthesis by the cultured cells was measured using a microplate assay (Xie et al., 1992). To measure the concentration of nitrite in the culture supernatant (an index of NO activity), aliquots (50 $\mu \mathrm{l})$ of culture medium were harvested and were incubated with an equal volume of Griess reagent $\quad(1 \%$ sulfanilamide/0.1\% N-(1-naphtyl)ethylenediamine dihydrochloride/2.5\% $\left.\mathrm{H}_{3} \mathrm{PO}_{4}\right)$ at room temperature for $10 \mathrm{~min}$. The absorbance of nitrite was measured at $540 \mathrm{~nm}$. The $\mathrm{NO}_{2}^{-}$content was determined by using sodium nitrite as a standard. To measure the release of TNF- $\alpha$, the culture supernatant from cells that had been stimulated with the $C$. japonica ethanol extract was collected and used with a mouse TNF- $\alpha$ enzymelinked immunosorbent assay kit according to the manufacturer's instructions.

\section{Western blot analysis}

RAW 264.7 cells were seeded at $1 \times 10^{5}$ cells $/ \mathrm{ml}$. After $16 \mathrm{~h}$, the cells were treated with $100 \mu \mathrm{g} / \mathrm{ml}$ of the $C$. japonica ethanol extract. The cells were then incubated for various periods at $37^{\circ} \mathrm{C}$. Cells were then collected and lysed by boiling for $5 \mathrm{~min}$ in $500 \mu \mathrm{l}$ of a solution of $120 \mathrm{mM} \mathrm{NaCl}, 0.1 \% \mathrm{NP} 40$, 
and $40 \mathrm{mM}$ Tris- $\mathrm{HCl}$ ( $\mathrm{pH}$ 8.0). Aliquots of the lysates (which each contained $\sim 40 \mu \mathrm{g}$ of protein) were electrophoresed on a $10 \%$ sodium dodecyl sulfate-polyacrylamide gel before the proteins were transferred to a nitrocellulose membrane (Bio-Rad, Hercules, CA, USA). The membrane was then incubated with primary mouse monoclonal antibody raised against inducible NOS (iNOS; Pharmingen, San Diego, CA) followed by incubation with a secondary goat anti-mouse immunoglobulin $G$ conjugated to horseradish peroxidase (Pierce, Rockard, IL, USA). The membrane was then exposed to X-ray film and protein bands were detected using an enhanced chemiluminescence Western blot detection kit (Amersham, Little Chalfont, Buckinghamshire, UK).

\section{Viability assay}

To determine the effect of the ethanol extracts on the viability of U937 human leukemic cells, cells were seeded in a 96-well plate at $1.0 \times 10^{5}$ cells $/ \mathrm{ml}$. Sixteen hours later, the cells were treated with various concentrations of the ethanol extract before being incubated for $72 \mathrm{~h}$ at $37^{\circ} \mathrm{C}$. An aliquot of a stock solution of MTT reagent $(50 \mu \mathrm{l} ; 2 \mathrm{mg} / \mathrm{ml})$ was then added to each well (total reaction volume: $200 \mu \mathrm{l}$ ). The cells were incubated for $4 \mathrm{~h}$, centrifuged at 800 $\times g$ for $5 \mathrm{~min}$, and the supernatants were aspirated. The formazan crystals in each well were dissolved in $150 \mu \mathrm{l}$ dimethyl sulfoxide and the absorbance at $540 \mathrm{~nm}$ was quantified using a spectrophotometer.

\section{RESULTS}

Effects of ethanol extract of $C$. japonica on NO production

NO production in RAW 264.7 cells treated with the C. japonica extract was determined by quantifying nitrite concentrations in culture supernatants after $48 \mathrm{~h}$ of culture in the presence of the C. japonica extract. As shown in Fig. 1, the ethanol extract caused a significant increase in $\mathrm{NO}$ production in the cells in a dose-dependent manner.

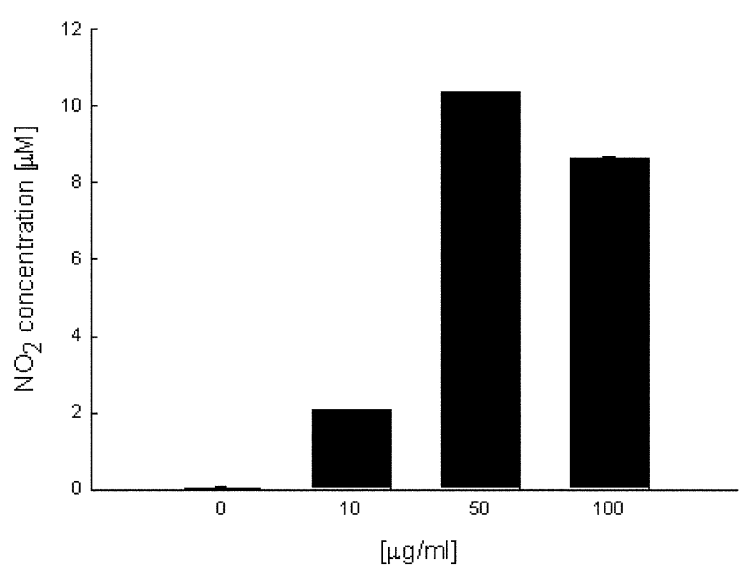

Fig. 1. Effect of an ethanol extract of $C$. japonica on the production of NO in RAW 264.7 cells. Cultured cells were incubated with various concentrations of the $C$. japonica extract (see Methods). After $48 \mathrm{~h}$ of incubation, NO release was measured by quantifying nitrite concentrations (the Griess method) in the culture medium. Data are the mean \pm standard error (S.E.) of three independent experiments.

\section{Effects of ethanol extract of $C$. japonica on iNOS expression}

iNOS production in RAW 264.7 cells treated with the C. japonica extract was determined using Western blot analysis. As shown in Fig. 2, the ethanol extract increased iNOS expression in the cells in a time-dependent manner.

\section{Inhibition of $C$. japonica extract-induced NO production by NMMA}

To determine whether the $C$. japonica extract-induced NO production in RAW 264.7 cells involved an L-arginine-dependent signaling pathway, we examined the effect of NMMA (a specific inhibitor of L-arginine-dependent NO production) (Hinz et al., 2000) on RAW 264.7 cells that were incubated for $48 \mathrm{~h}$ in the presence of the C. japonica extract. As shown in Fig. 3, C. japonica extract-induced NO production was inhibited by NMMA in a dosedependent manner.

\section{Inhibition of C. japonica extract-induced NO production by PDTC}

To elucidate the signaling mechanism through 

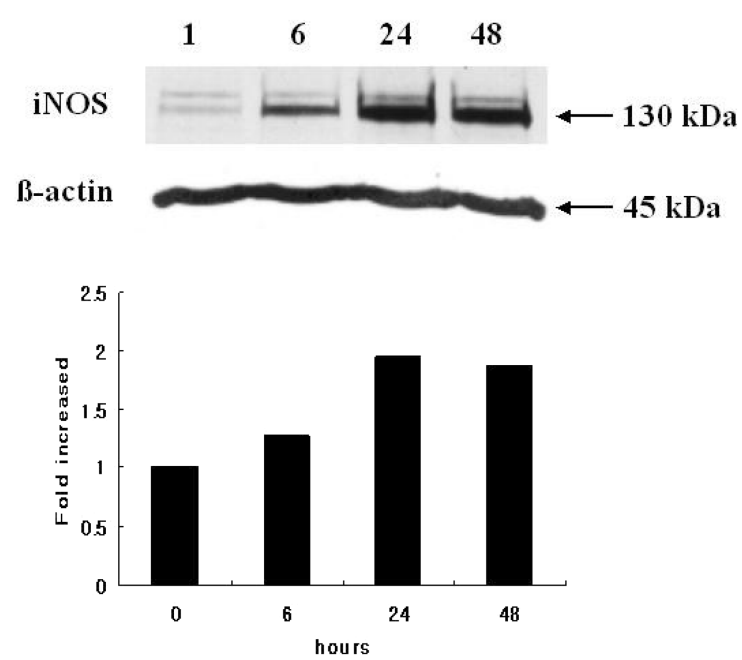

Fig. 2. Effect of an ethanol extract of $C$. japonica on the expression of iNOS in RAW 264.7 cells. Cultured cells were incubated with $100 \mu \mathrm{g} / \mathrm{ml}$ of the C. japonica extract. After various incubation times (see Methods), proteins were extracted and iNOS expression was quantified using Western blot analysis (A). The iNOS levels were quantified by densitometric analysis (B).

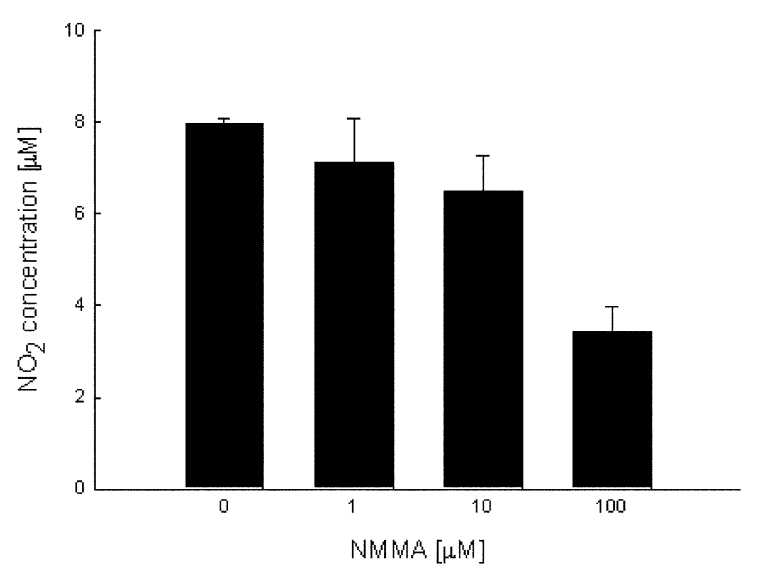

Fig. 3. Effect of NMMA on C. japonica extract-induced NO production in RAW 264.7 cells. Cultured cells were incubated with NMMA for $6 \mathrm{~h}$. The cells were then treated with C. japonica extract $(100 \mu \mathrm{g} / \mathrm{ml})$ and cultured for an additional $48 \mathrm{~h}$. NO release was measured by quantifying nitrite concentrations (the Griess method) in the culture medium. Data are the mean \pm S.E. of three independent experiments.

which the C.japonica extract induced $\mathrm{NO}$ production in RAW 264.7 cells, we examined the effect of PDTC (an antioxidant compound that inhibits NF$\kappa \mathrm{B}$ activation) (Schreck et al., 1992) on RAW 264.7

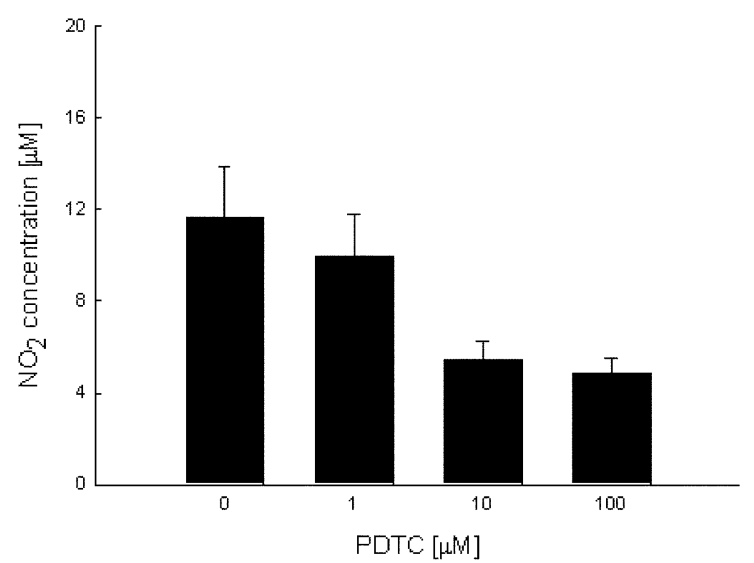

Fig. 4. Effect of PDTC on C. japonica extract-induced NO production in RAW 264.7 cells. Cultured cells were incubated with PDTC for $6 \mathrm{~h}$. The cells were then treated with $C$. japonica extract $(100 \mu \mathrm{g} / \mathrm{ml})$ and cultured for an additional $48 \mathrm{~h}$. NO release was measured by quantifying nitrite concentrations (the Griess method) in the culture medium. Data are the mean \pm S.E. of three independent experiments.

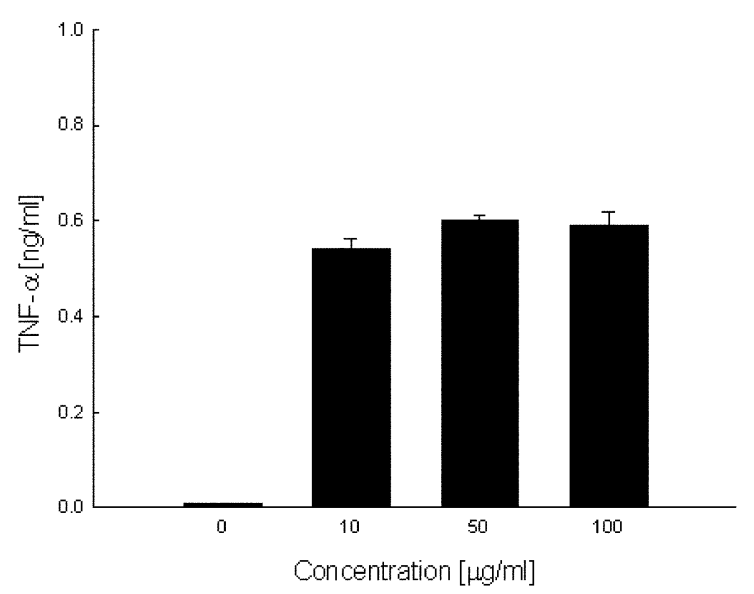

Fig. 5. Effect of $C$. japonica extract on the production of TNF- $\alpha$ in RAW 264.7 cells. Cultured cells were incubated with various concentrations of the $C$. japonica extract (see Methods). After $48 \mathrm{~h}$ of incubation, the amount of TNF- $\alpha$ secreted by RAW 264.7 cells was measured using an enzyme-linked immunosorbent assay. Data are the mean \pm S.E. of three independent experiments.

cells that were incubated for $48 \mathrm{~h}$ in the presence of the C. japonica extract. As shown in Fig. 4, C. japonica extract-induced $\mathrm{NO}$ production was inhibited by PDTC in a dose-dependent manner. 


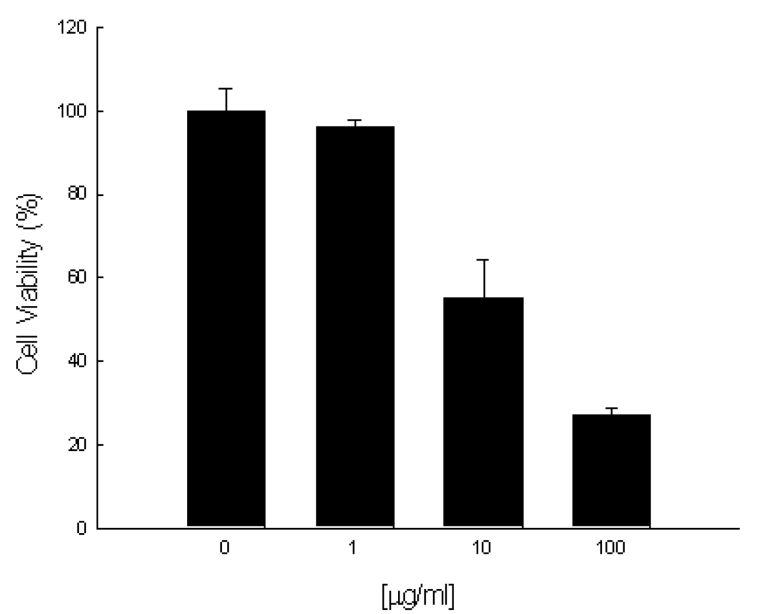

Fig. 6. Effect of $C$. japonica extract on the viability of human U937 leukemic cells. Cell viability was evaluated using a colorimetric MTT assay $72 \mathrm{~h}$ after the exposure of U937 cells to the C. japonica extract (see Methods). Data are the mean \pm S.E. of three independent experiments.

Effect of $C$. japonica extract on TNF- $\alpha$ production We examined the effect of the $C$. japonica extract on TNF- $\alpha$ production in RAW 264.7 cells. RAW 264.7 cells secreted very low levels of TNF- $\alpha$ after $48 \mathrm{~h}$ of incubation with medium alone, whereas the addition of the $C$. japonica extract caused an increase in TNF- $\alpha$ production in a dose dependent manner (Fig. 5).

Effect of the C. japonica extract on the viability of U937 cells

To test whether the $C$. japonica extract would affect the growth of human leukemic monoblasts, we evaluated the effect of the extract on the viability of U937 leukemic cells. As shown in Fig. 6, the ethanol extract caused direct inhibition of the viability of U937 cells in a dose dependent manner.

\section{DISCUSSION}

In the present study, we demonstrated that an ethanol extract of $C$. japonica caused an increase in the production of NO in cultured macrophage-like RAW 264.7 cells. The C. japonica-extract-induced
NO production occurred through the induction of iNOS expression; this was supported by the observation that NMMA (an analogue of L-arginine) inhibited C. japonica-extract-induced NO production. At present, the precise physiological significance of the induction of $\mathrm{NO}$ production by $\mathrm{C}$. japonica is unknown. However, NO synthesis is important in host defenses against pathogens and cancers (Gantt et al., 2001). In addition, NO has emerged as an important intracellular and intercellular regulatory molecule with functions as diverse as vasodilation, neural communication, cell growth regulation, and host defense (Chung et al., 2002, 2004). NO generation by iNOS also influences the cytotoxicity of macrophages and tumor-induced immunosuppression. The induction of NO production by C. japonica extract suggests that this plant contains a substance(s) that has antimicrobial, antitumoral, and antiviral activity. Indeed, we found that the ethanol extract of $C$. japonica inhibited cell growth of human U937 leukemic cells, which is a macrophage cell line. In a previous study, human granulocyte-macrophage colony-stimulating factor (GM-CSF) inhibited the colony growth of U937 cells in agar culture that was partially due to the presence of TNF (Cannistra et al., 1987). It suggest that one of mechanisms that is inhibited U937 cells by extract of $C$. japonica may be the production of TNF- $\alpha$ (Eue et al., 1995) and nitric oxide (Eue et al., 1995; Bertholet et al., 1999).

It has been reported that NO synthesis is greatly diminished by neutralization with an anti-TNF- $\alpha$ antibody (Kim et al., 1999). Chelidonium majus and Sinomenium acutum stem (SSAE) increased the production of NO and TNF- $\alpha$ from rIFN-gamma mouse peritoneal macrophages (Kim et al., 1999; Chung et al., 2004). Our results suggest that the NO synthesis that is induced by C. japonica in RAW 264.7 cells could be synergistically associated with TNF- $\alpha$ secretion triggered by the C. japonica extract, even though the extract itself induced only a low level of TNF- $\alpha$ secretion.

$\mathrm{NF}-\kappa \mathrm{B}$ is expressed ubiquitously and plays a 
major role in controlling the expression of proteins that are involved in inflammatory reaction and acute-phase immune responses (Baeuerle and Henkel, 1994). Expression of iNOS and TNF- $\alpha$ genes depends on the activation of NF-KB (Yu et al., 2004). We found in the present study that the addition of an inhibitor of NF-kB, PDTC, inhibited C. japonica extract-induced NO production. This suggests that C. japonica extract increases the production of $\mathrm{NO}$ and TNF- $\alpha$ through the activation of NF- $\mathrm{kB}$.

In summary, $C$. japonica would appear to have important effects on immune-related cellular activities through the generation of NO and TNF- $\alpha$. The precise mechanism by which $C$. japonica induces NO and TNF- $\alpha$ production remains to be elucidated.

\section{ACKNOWLEDGEMENTS}

This research was performed under the program of Basic Atomic Energy Research Institute (BAERI) which is a part of the Nuclear R\&D Programs funded by the Ministry of Science \& Technology (MOST) of Republic of Korea.

\section{REFERENCES}

Baeuerle PA, Henkel T. (1994) Function and activation of NF-kappa B in the immune system. Annu. Rev. Immunol. 12, 141-179.

Bertholet S, Tzeng E, Felley-Bosco E, Mauel J. (1999) Expression of the inducible NO synthase in human monocytic U937 cells allows high output nitric oxide production. J. Leukoc. Biol. 65, 50-58.

Cannistra SA, Rambaldi A, Spriggs DR, Herrmann F, Kufe D, Griffin JD. (1987) Human granulocytemacrophage colony-stimulating factor induces expression of the tumor necrosis factor gene by the U937 cell line and by normal human monocytes. J. Clin. Invest. 79, 1720-1728.

Chung HS, An HJ, Jeong HJ, Won JH, Hong SH, Kim HM. (2004) Water extract isolated from Chelidonium majus enhances nitric oxide and tumour necrosis factor-alpha production via nuclear factor-kappaB activation in mouse peritoneal macrophages. J.
Pharm. Pharmacol. 56, 129-134.

Chung HS, Jeong HJ, Hong SH, Kim MS, Kim SJ, Song BK, Jeong IS, Lee EJ, Ahn JW, Baek SH, Kim HM. (2002) Induction of nitric oxide synthase by Oldenlandia diffusa in mouse peritoneal macrophages. Biol. Pharm. Bull. 25, 1142-1146.

Eue I, Zeisig R, Arndt D. (1995) Alkylphosphocholineinduced production of nitric oxide and tumor necrosis factor alpha by U 937 cells. J. Cancer Res. Clin. Oncol. 121, 350-356.

Gantt KR, Goldman TL, McCormick ML, Miller MA, Jeronimo SM, Nascimento ET, Britigan BE, Wilson ME. (2001) Oxidative responses of human and murine macrophages during phagocytosis of Leishmania chagasi. J. Immunol. 167, 893-901.

Hinz B, Brune K, Pahl A. (2000) Nitric oxide inhibits inducible nitric oxide synthase mRNA expression in RAW 264.7 macrophages. Biochem. Biophys. Res. Commun. 271, 353-357.

Kang KA, Bu HD, Park DS, Go GM, Jee Y, Shin T, Hyun JW. (2005) Antioxidant activity of ethanol extract of Callophyllis japonica. Phytother. Res. 19, 506-510.

Kim HM, Moon YH. (1996) Human chorionic gonadotropin induces nitric oxide synthase mRNA in mouse peritoneal macrophages. Biochem. Biophys. Res. Commun. 229, 548-552.

Kim HM, Moon EJ, Li E, Kim KM, Nam SY, Chung CK. (1999) The nitric oxide-producing activities of Scutellaria baicalensis. Toxicology 135, 109-115.

Kim HM, Oh DI, Chung CK. (1999) Production of nitric oxide in mouse peritoneal macrophages after priming with interferon-gamma by the stem of Sinomenium acutum. J. Ethnopharmacol. 66, 311-317.

Nathan CF, Hibbs JB Jr. (1991) Role of nitric oxide synthesis in macrophage antimicrobial activity. Curr. Opin. Immunol. 3, 65-70.

Park D, Lee K, Kim H, Ahn M, Moon C, Ko M, Lee K, Go K, Shin T. (2005) Effect of Callophyllis japonica powder on carbon tetrachloride-induced liver injury in rats. Orient. Pharm. Exp. Med. 5, 231-235.

Schreck R, Meier B, Mannel DN, Droge W, Baeuerle PA. (1992) Dithiocarbamates as potent inhibitors of nuclear factor kappa B activation in intact cells. J. Exp. Med. 175, 1181-1194.

Xie QW, Cho HJ, Calaycay J, Mumford RA, Swiderek KM, Lee TD, Ding A, Troso T, Nathan C. (1992) 
Cloning and characterization of inducible nitric oxide synthase from mouse macrophages. Science 256, 225-228.

Yu Z, Zhao L, Ke H. (2004) Potential role of nuclear factor-kappa $B$ in the induction of nitric oxide and tumor necrosis factor-alpha by oligochitosan in macrophages. Int. Immunopharmacol. 4, 193-200.

Zhou X, Potoka DA, Boyle P, Nadler EP, Mcginnis K, Ford HR. (2002) Aminoguanidine renders inducible nitric oxide synthase knockout mice more susceptible to Samonella typhimurium infection. FEMS Microbiol. Lett. 206, 93-97. 